\title{
ジュニアスポーツ選手の食事について考えるーJISS の調查・研究よりー
}

\author{
亀 井明子
}

(国立スポーツ科学センター)

近年，女性アスリートの栄養問題が示されている. JISSではこれまで女性トップアスリートを対象とした調 查・研究を行い, トップアスリートの栄養上の課題につ いて示してきた，今回はこれらの研究を紹介し女性トッ プアスリートの食事や食生活を題材にしながら, 成長期 年代のジュニアスポーツ選手の食事について考えたい.

無月経及び月経不順アスリートと正常月経アスリート の食生活状況を質問紙調査により検討した ${ }^{1)}$ ．体重の意 識について「体重を減らしたいと思うか」の問いで月経 状況との間に有意な関連があり, 月経周期正常群では「全 く思わない」と回答した者の割合が無月経及び月経不順 群に比べ有意に高値を示した。しかし, 食物摂取頻度で は群間に有意な差はみられなかったことから, 月経周期 に問題のあるアスリートの栄養教育では, 実際の摂取量 を把握しlow energy availabilityと考えられる場合には, 具体的な摂取量を示したアドバイスが必要と考える。ま た食事改善においては，無月経は低体重が要因でもある ため, 体重及び体組成の変化やパフォーマンスを確認し, 指導者と話合いながら栄養介入を行うことも重要となる. energy availability (以下, EA) が45 kcal/kg FFM/ day未満の無月経アスリートを対象に, エネルギー改善 を目的とした栄養指導を 3 か月間行い，EAと体重捛よ びホルモン值の関連について検討した ${ }^{2)}$. 介入前後で体 重, 体組成及びEAに有意差は見られなかった，介入後 に増加した者は 4 名, 介入後に減少した者が 2 名だった。 $\mathrm{EA}$ の変化とその内訳から, EAが増加した 4 名のうち 3 名は, 介入後で総エネルギー摂取量は低下したが, 運動 によるエネルギー消費量が低下したことでEAが増加し た、 $\mathrm{EA} の$ 低下がみられた 2 名のうち 1 名は, 総エネル ギー摂取量全体は介入後に増加したが, 運動によるエネ ルギー消費量が増加したことで, 結果的にEAが低下し た，EAの変化は，運動によるエネルギー消費量の影響 も大きいのではないかと考える，EAとLHの個人毎の 変化をみると, EAが増加した者はLHも増加し, EAが 低下した者はLHも低下し, EA と LHが同様に変動した。 3 か月間の栄養指導介入の結果, 月経の回復はみられな かった、アスリートでは, 年間を通じて期別による運動 量の変動や特徵を把握し, EA や体重, 体組成, 血液状態 等の確認をしながら 3 ケ月以上の長期的な栄養介入が必 要である.

女子陸上中長距離選手の実際の通常練習時に抢ける筋 グリコーゲン (Gly) 動態と炭水化物摂取量について事例 的に調查した ${ }^{3)}$. 通常練習の午前練習前後, 午後練習後,
翌朝に, 炭素磁気共鳴分光法 ${ }^{13} \mathrm{C}-\mathrm{MRS}$ を用いた下腿三頭 筋の Gly 濃度測定，体重及び体組成測定を行った，期間 中の飲食物は自由摂取とし, 食事調査からエネルギー及 び炭水化物摂取量 $(\mathrm{CHO})$ を算出した。練習内容記録 と活動量測定結果からエネルギー消費量を評価し，EA を算出した。翌朝までに筋 Gly 濃度が $75 \%$ 程度までし か回復しなかった選手のEAは13.9 kcal/kg FFM/day, CHOは $4.9 \mathrm{~g} / \mathrm{kg} \mathrm{BM} /$ dayであった。一方，94\%程度ま で回復した選手の EAは $31.1 \mathrm{kcal} / \mathrm{kg} \mathrm{FFM} /$ day, CHOは $7.5 \mathrm{~g} / \mathrm{kg} \mathrm{BM} /$ day であった。 翌朝までの筋グリコーゲン 回復のためには, 必ずしも十分な食事摂取ができてない 実態が明らかとなった. EAが $30 \mathrm{kcal} / \mathrm{kg} \mathrm{FFM/dayを下}$ 回り, 活動強度及び活動内容に該当する炭水化物量を摂 取できていない場合には，翌朝までに筋グリコーゲンが 回復しない可能性が示された。目常の適切な炭水化物摂 取が筋グリコーゲンの回復には必要である.

これらトップアスリートの調查・研究からわかったこ とは, EAを予防し, 改善するためには,「食事摂取量と エネルギー消費量の評価」「体重・体組成のモニタリン グ」,「具体的な摂取量を示したアドバイス」,「指導者, 保護者, 各専門分野のスタッフとの連携」が重要であり, 予防のためには「ジュニア期からの栄養教育」が必要で ある。

成長期年代において正しい生活習慣と十分なエネル ギー及び栄養素摂取のできる食習慣を身に付けることが 健康的なからだと将来のアスリートとしてのからだをつ くることになる。ジュニア期からの栄養教育では, 学校 教育現場で日常的・継続的に栄養支援を行っている栄養 教諭の役割が重要となる，栄養教諭の中には，スポーツ 栄養の専門的知識とスキルを身に付けた公認スポーツ栄 養士の資格を取得している方もいる，地域のスポーツ現 場では，ジュニアアスリートを支える専門家として公認 スポーツ栄養士の役割も重要となるだろう。

参考文献

1. 石井美子他, 女性トップアスリートに扔ける月経状況と 食生活状況との関連, 第 3 回日本スポーツ栄養学会学術 集会, 2016

2. 石井美子他, 無月経トップアスリートへの栄養指導によ る energy availability と黄体化ホルモンの変化の検討, 日本臨床スポーツ医学会誌（印刷中）

3. 亀井明子他, 女子陸上中長距離選手の通常練習時に㧍け る筋グリコーゲン動態と炭水化物量, 第28回日本臨床 スポーツ医学会学術集会, 2017 